\title{
Aplikasi Kesehatan Ibu Hamil Berbasis Android
}

\author{
${ }^{1}$ Ardianto Pambudi, ${ }^{2}$ Nurchim*, ${ }^{3}$ Agustina Srirahayu \\ ${ }^{123}$ Fakultas Ilmu Kemputer, Universitas Duta Bangsa Surakarta \\ *nurchim@udb.ac.id
}

\begin{abstract}
Abstrak
Di Indonesia, tingkat kematian ibu hamil masih tinggi. Salah satu faktor penyebabnya karena kurangnya pengetahuan dan kesadaran komunikasi ibu hamil dengan bidan dalam proses pemeriksaan kehamilan sehingga mengakibatkan terlambatnya mengenali tanda bahaya kehamilan. Tujuan penelitian ini menyediakan aplikasi Kesehatan ibu hamil yang dapat dijalankan pada sistem android. Android sebagai sistem operasi smartphone, mendukung pengembangan ide dan inovasi aplikasi baru guna menambah fungsionalitas sistem. Tahapan pembuatan aplikasi meliputi (1) menganalisis kebutuhan pengguna dengan cara melakukan pengamatan di Bidan Praktik Mandiri daerah Polokarto Sukoharo Jawa Tengah. Selanjutnya, (2) membuat desain sistem yang terdiri dari dua pengguna antara lain bidan dan ibu hamil. Terakkhir, (3) implementasi pembuatan desain sistem dalam bentuk aplikasi android. Aplikasi Kesehatan ibu hamil ini memiliki fitur bahwa ibu hamil dapat berkomunikasi dengan bidan secara langsung menyampaikan keluhan, hasil pemeriksaan, informasi seputar kehamilan dan perhitungan Hari Perkiraan Lahir (HPL). Dengan demikian, diharapkan aplikasi ini dapat dijadikan layanan Kesehatan digital yang memudahkan akses informasi dan layanan Kesehatan masyrakat terutama berkaitan dengan kehamilan.
\end{abstract}

Kata Kunci: kehamilan, bidan, android, kesehatan

In Indonesia, the mortality rate for pregnant women is still high. One of the contributing factors is the lack of knowledge and awareness of communication between pregnant women and midwives in the process of antenatal care, resulting in a delay in recognizing the danger signs of pregnancy. The purpose of this study is to provide a pregnant mother's health application that can be run on an android system. Android as a smartphone operating system, supports the development of new application ideas and innovations to add system functionality. The stages of making the application include (1) analyzing user needs by observing the Independent Practice Midwife in the Polokarto Sukoharo area, Central Java. Next, (2) design a system consisting of two users, including midwives and pregnant women. Finally, (3) the implementation of making a system design in the form of an android application. This Maternal Health Application has a feature that pregnant women can communicate with midwives directly to submit complaints, examination results, information about pregnancy and the calculation of Estimated Birth Days (HPL). Thus, it is hoped that this application can be used as a digital health service that facilitates access to information and public health services, especially those related to pregnancy.

Keywords: pregnancy, midwife, android, health

\section{PENDAHULUAN}

Tingkat Angka Kematian Ibu hamil di Indonesia masih sangat tinggi (Aji dkk., 2018). Masalah kehamilan dan persalinan merupakan hal yang alami, namun bukan berarti tidak ada resiko (Baroroh dkk., 2017). Penyebab kematian ibu hamil disebabkan penanganan yang kurang baik dan tepat sehingga terlambat mengenali tanda bahaya, merujuk dan pelayanan yang optimal (Respati dkk., 2019). Selain itu, banyak ibu hamil yang kurang menyadari pentingnya pemeriksaan sebagai upaya deteksi faktor resiko yang dialami selama kehamilan (Nur dkk., 2018).

Kurangnya pengetahuan saat masa kehamilan, membuat ibu hamil menghiraukan timbulnya gejala-gejala penyakit berbahaya tertentu yang secara tidak langsung menjadi penyebab kematian ibu hamil (Aji dkk., 2018). Kondisi ini mungkin disebabkan rendahnya tingkat komunikasi, informasi dan edukasi tentang kesehatan ibu hamil sehingga pendidikan kesehatan sangatlah penting dalam menunjang program kesehatan (Nur dkk., 2018). Kajian penelitian sebelumnya, kendala komunikasi terapeutik antara bidan dengan ibu hamil dipengaruhi adanya hambatan bahasa, budaya dan psikologis (Prasanti \& Fuady, 2017). Salah satu terobosan yakni pembentukan kelas ibu hamil sebagai sarana belajar bersama agar ibu hamil mempunyai pengetahuan yang cukup berkaitan kehamilan, namun tingkat partisipasinya masih rendah (Baroroh dkk., 2017).

Tujuan penelitian ini adalah menyediakan aplikasi kesehatan ibu hamil sebagai sarana komunikasi ibu hamil dengan bidan dalam memperoleh pengetahuan dan menyampaikan keluhan tentang kehamilan secara langsung. Aplikasi ini dapat dijalankan melalui smartphones android, yang saat ini berkembangnya pesat penggunaannya di 
masyarakat (Alfarisi, 2019). Pemanfaatan teknologi informasi dalam kesehatan ini dikenal dengan istilah digital health atau seringnya juga disebut telekesehatan (telehealth) yang banyak membawa keuntungan seperti pertukaran informasi medis antara pasien dengan tenaga kesehatan, layanan kesehatan dalam rangka diagnosis differential, akses kesehatan lebih efisien dan cost effective (Sunjaya, 2019). Dengan demikian, perlu dilakukan pembuatan aplikasi Kesehatan ibu hamil sebagai upaya untuk membantu mengurangi angka kematian ibu hamil.

\section{TINJAUAN PUSTAKA}

Kehamilan adalah proses fertilisasi atau penyatuan dari spermatozoa dan ovum, yang dialami seorang perempuan dalam waktu 9 bulan 1 minggu dan terbagi menjadi 3 trimester (Hikmatulloh dkk., 2019). Selama proses kehamilan tersebut, kondisi kesehatan, status mental dan gaya hidup mempengaruhi komplikasi pada kehamilan yang berpeluang menyebabkan kematian ibu dan janin (Dewi, 2017). Deteksi dini kehamilan perlu ditingkatkan dalam pelayanan kunjungan antenatal care (pemeriksaan kehamilan) (Putri, Mutiara \& Ismiyatun, 2020). Oleh karena itu, dukungan fasilitas kesehatan yang mudah diakses dibutuhkan dalam antenatal care sebagai upaya menjaga kesehatan ibu hamil dan bayi (Dharmayanti dkk., 2019).

Layanan Kesehatan digital hadir di masyarakat, dengan ragam pilihan layanan sesuai dengan preferensi dan kebutuhan kesehatan masyarakat (Indriyanti \& Wibowo, 2020). Salah satunya, melalui layanan kesehatan berbasis seluler berpotensi dan bermanfaat meningkat praktik antenatal care secara positif dalam mempengaruhi perilaku ibu hamil (Selvia \& Ernawati, 2019). Android merupakan sistem operasi seluler yang berkembang pesat di smartphones saat ini, mendukung pengembangan ide dan inovasi aplikasi baru untuk menambah fungsionalitas sistem (Sarumaha dkk., 2020). Peluang ini, dapat dimanfaatkan untuk pengembangan aplikasi layanan kesehatan yang dapat diakses masyarakat melalui sistem android (Agustha \& Fachrizal, 2017) agar mudah mendapatkan informasi dan layanan kesehatan.

\section{METODE}

Metode yang digunakan dalam mengembangkan sistem ini adalah metode Rapid Aplication Development (RAD), yang mempunyai langkah-langkah sebagai berikut (Tamrin \& Ma'arif, 2020):

1. Requirement Planning (rencana kebutuhan)

Pengumpulan data berkaitan masalah komunikasi ibu hamil. Observasi dilakukan dengan cara wawancara dengan salah satu Bidan
Praktik Mandiri di daerah kecamatan Polokarto Kabupaten Sukoharjo Jawa Tengah.

2. Design System (desain sistem)

Tahapan ini pengembang bersama pengguna melakukan identifikasi tujuan dari sistem dan kebutuhan informasi. Kegiatan yang dilakukan yakni membuat pemodelan sistem kesehatan ibu hamil.

3. Implementation (implementasi)

Terakhir adalah tahapan pembuatan sistem Kesehatan ibu hamil yang dapat dioperasikan pada android yang terdapat 2 pengguna yaitu bidan dan ibu hamil.

\section{HASIL DAN PEMBAHASAN \\ Desain Sistem}

Desain aplikasi yang dikembangkan ini menggunakan pendekatan diagram Unified Modelling Language (UML) yang dijelaskan sebagai berikut:

\section{a. Use Case Diagram}

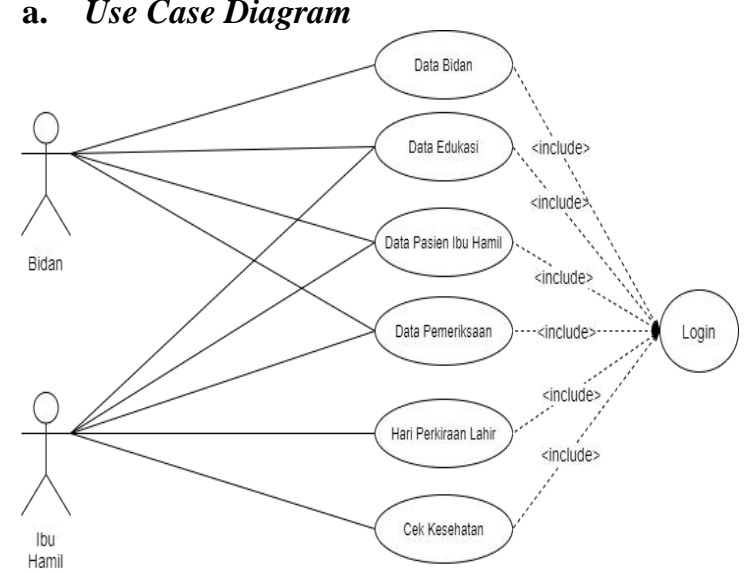

Gambar 1. Use Case Diagram

\section{b. Class Diagram}

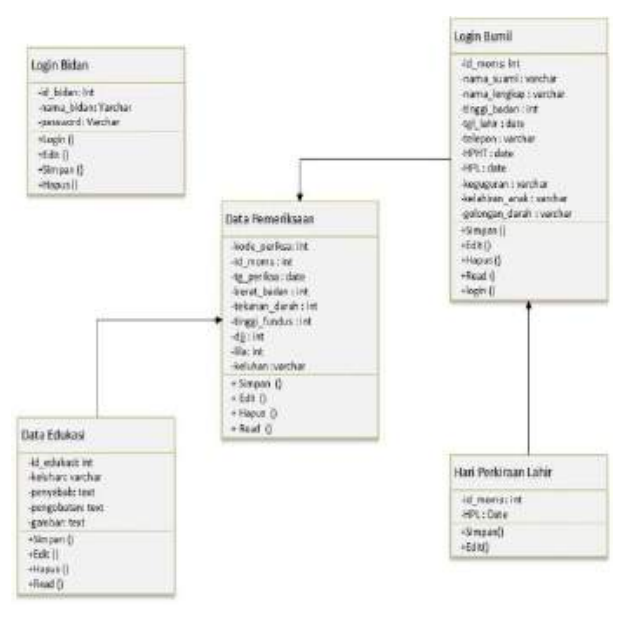

Gambar 2. Class Diagram 


\section{c. Relasi Antar Tabel}
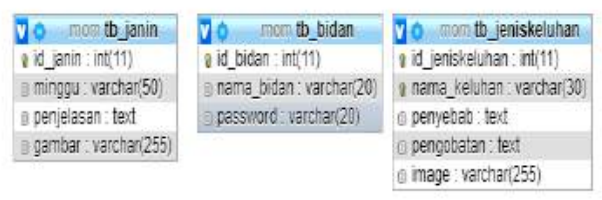

Vo thomoms

i id_moms : int(11)

0. nama_lengkap varchar(50)

Q 0 nama_suami varchar (50)

4 tinggi badan ir: (4)

I0 tgl_lahir: date

(0) telepon: varchar'133

In hipht date

[1) hol: date

- keguguran varchar(20)

to kalahima

o golongan_darah : varchar(5)

Gambar 3. Relasi Antar Tabel

\section{Implementasi}

Implementasi aplikasi ini terbagi menjadi dua aktor yaitu bidan dan ibu hamil:

1) Bidan

a. Registrasi Bidan

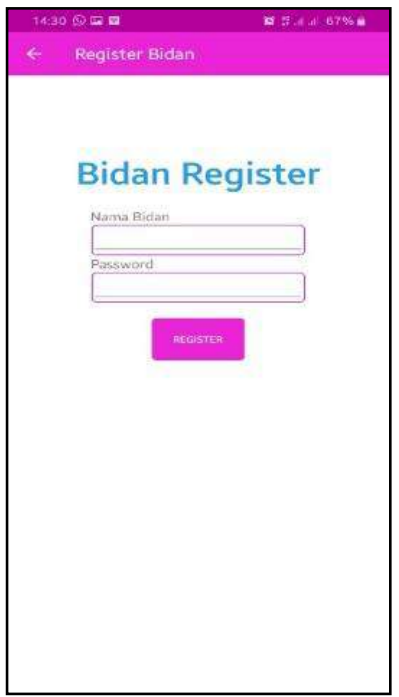

Gambar 4. Antarmuka Bidan Register

Antarmuka ini adalah Antarmuka aplikasi untuk bidan, dimana bidan melakukan registrasi akun bidan yang digunakan untuk login. Di dalam tampilan ini terdapat komponen Edit Text nama bidan, Edit Text password dan Button simpan. Button simpan berfungsi menyimpan data bidan yang telah dimasukan di Edit Text nama bidan dan password ke server database. b. Antarmuka Halaman Utama

Terdapat menu profile, pasien baru, input data keluhan, input data perkembangan janin, hasil pemeriksaan dan data pasien. Menu profile berfungsi untuk menampilkan halaman pofile. Menu pasien baru berfungsi untuk menampilkan halaman form data pasien baru, Menu input data keluhan berfungsi untuk menampilkan halaman input data keluhan. Menu input data perkembangan janin digunakan untuk menampilkan halaman data perkembangan janin. Menu hasil pemeriksaan digunakan untuk menampilkan halaman data pemeriksaan. Menu data pasien digunakan untuk menampilkan data pasien.

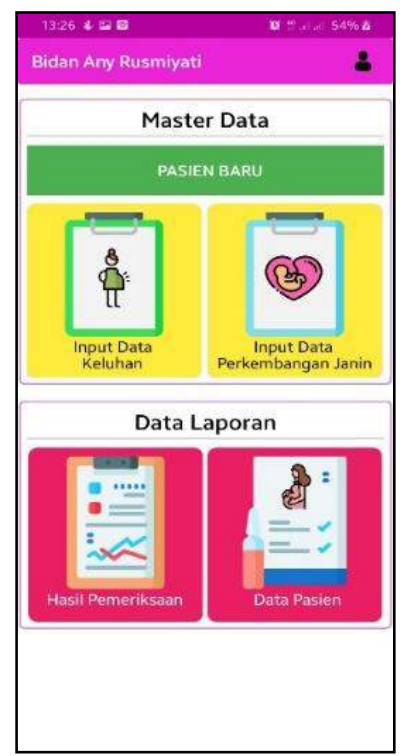

Gambar 5. Halaman Utama Bidan

c. Halaman Profile Bidan

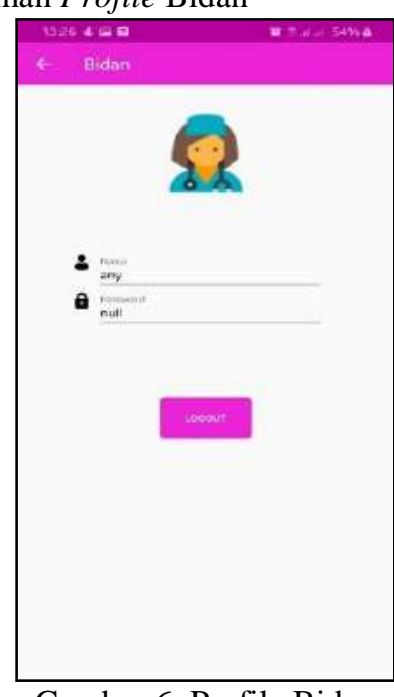

Gambar 6. Profile Bidan

Halaman profile bidan dimana terdapat Edit Text nama, Edit Text password, button kembali dan button logout. Button kembali digunakan untuk kembali ke menu halaman utama. Button 
logout digunakan untuk keluar dari aplikasi bidan.

\section{d. Halaman Pasien Baru}

Halaman pasien baru dimana terdapat Edit Text nama lengkap, Edit Text nama suami, Edit Text tinggi badan, Date tanggal lahir, Edit Text telepon, Edit Text alamat, Date HPHT, Spinner keguguran, Spinner kelahiran anak, Spinner golongan darah dan Button register. Button Register digunakan untuk menyimpan data ke database yang telah diinputkan.

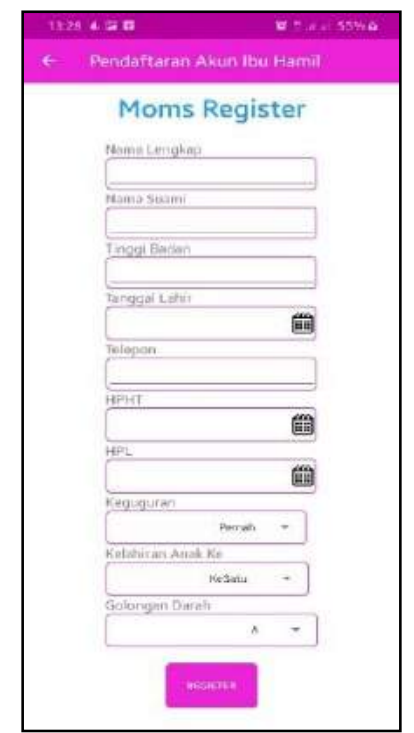

Gambar 7. Antarmuka Pasien Baru

e. Data Keluhan

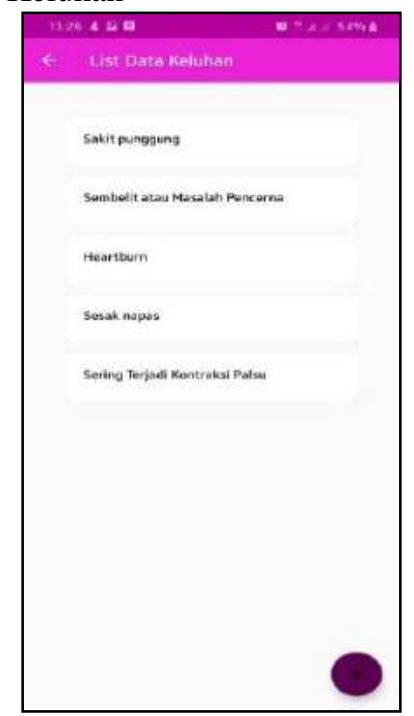

Gambar 8. List Data Keluhan

List data keluhan dimana terdapat texview yang menampilkan data keluhan.Button tambah digunakan untuk pindah ke halaman tambah data keluhan.Button back digunakan untuk kembali ke menu halaman utama.

f. Tambah Data Keluhan
Halaman aplikasi tambah data keluhan dimana terdapat Edit Text nama keluhan, Edit Text penyebab, Edit Text pengobatan dan Edit Text gambar. Button simpan digunakan untuk menyimpan data keluhan. Button kembali digunakan untuk kembali ke halaman list data keluhan

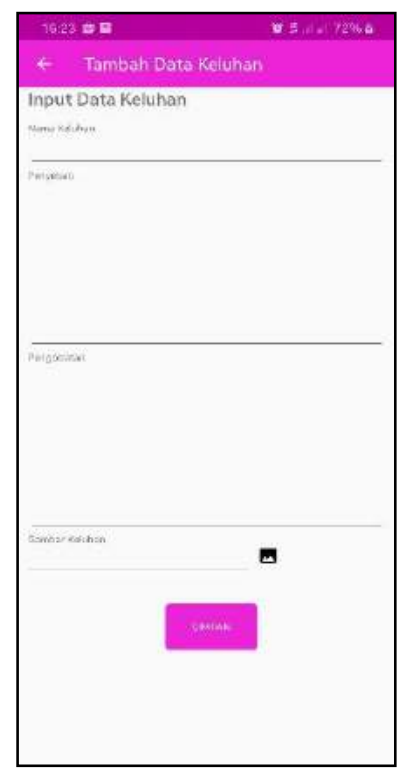

Gambar 9. Tambah Data Keluhan

g. List Data Janin

Halaman list data janin dimana terdapat texview yang menampilkan data janin.Button tambah digunakan untuk pindah ke halaman tambah data janin.Button back digunakan untuk kembali ke menu halaman utama.

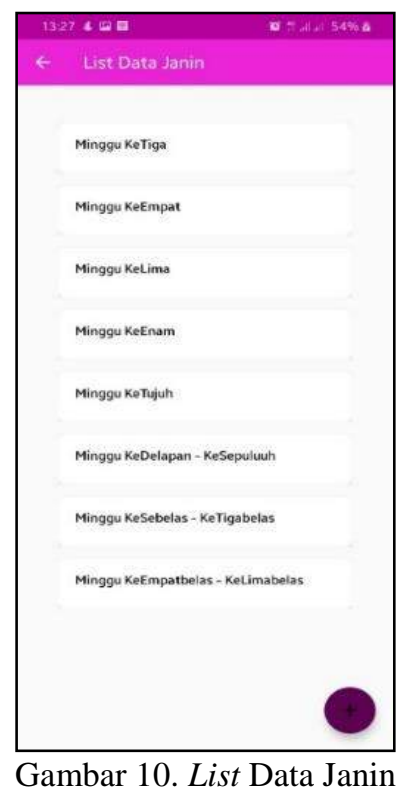

h. Tambah data Janin

Halaman aplikasi tambah data janin dimana terdapat Edit Text minggu, Edit Text penjelasan, dan Edit Text gambar. Button simpan digunakan 
untuk menyimpan data janin. Button kembali digunakan untuk kembali ke halaman list data janin.

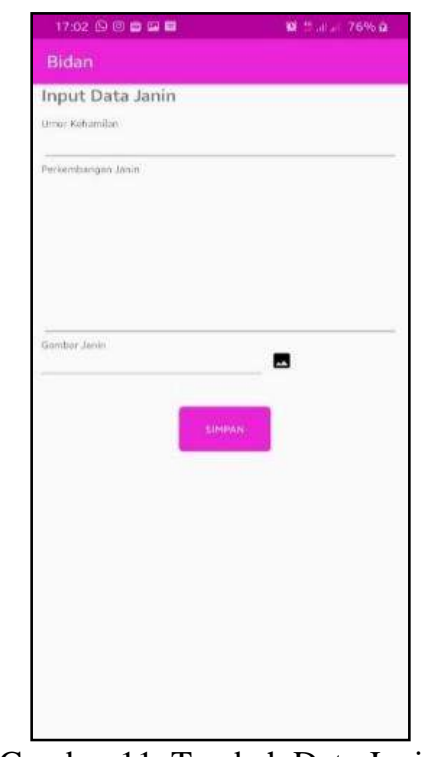

Gambar 11. Tambah Data Janin

i. Halaman Daftar Ibu Hamil

Halaman daftar ibu hamil dimana terdapat texview yang menampilkan data ibu hamil. Button back digunakan untuk kembali ke menu halaman utama.

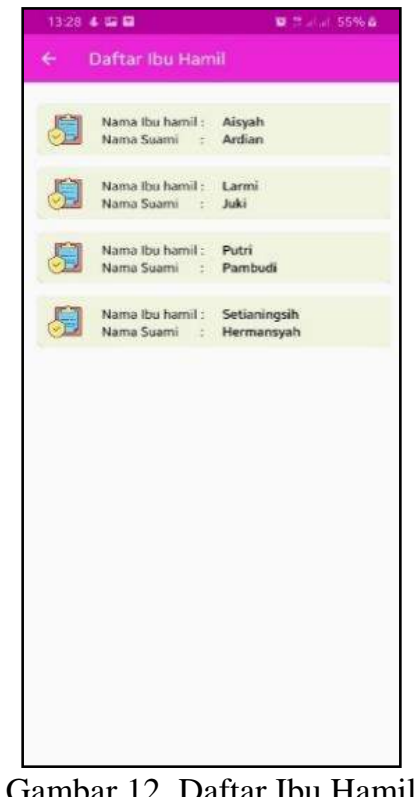

j. List Periksa Pasien

Halaman list periksa pasien dimana terdapat texview yang menampilkan data periksa. Button tambah digunakan untuk pindah ke halaman tambah data pemeriksaan.Button edit digunakan untuk pindah ke halaman update data pemeriksann. Button hapus digunakan untuk menghapus data periksa Button back digunakan untuk kembali ke menu halaman utama.

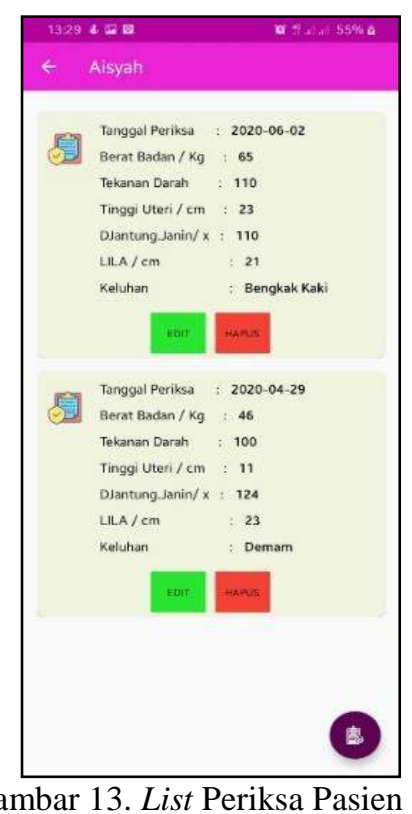

2) Ibu Hamil

a. Registrasi Ibu Hamil

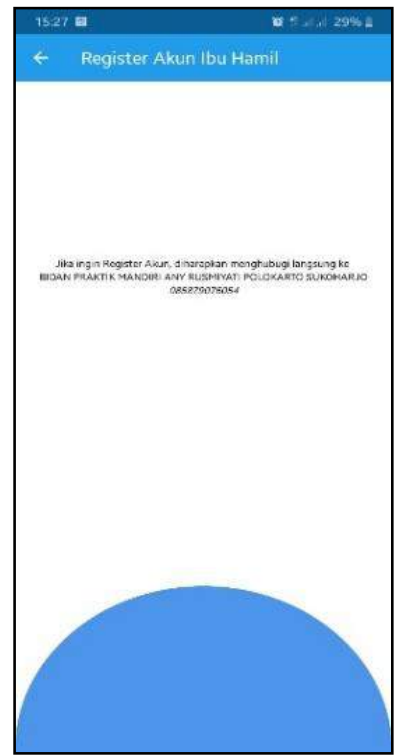

Gambar 14. Antarmuka Register Ibu Hamil

Halaman register ibu hamil dimana terdapat textview yang berupa infomasi Bidan Praktik Mandiri.

\section{b. Login Ibu Hamil}

Halaman Login ibu hamil terdapat button Login serta ada edit text telepon dan nama ibu hamil. Tombol login berfungsi untuk masuk dalam aplikasi ibu hamil. 


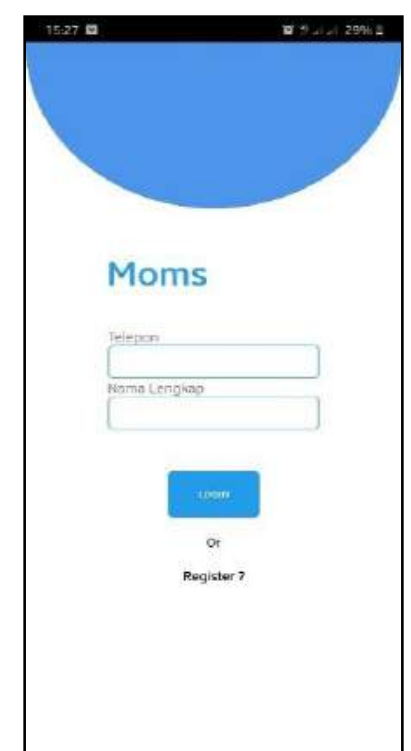

Gambar 15. Login Ibu Hamil

c. Menu Halaman Ibu Hamil

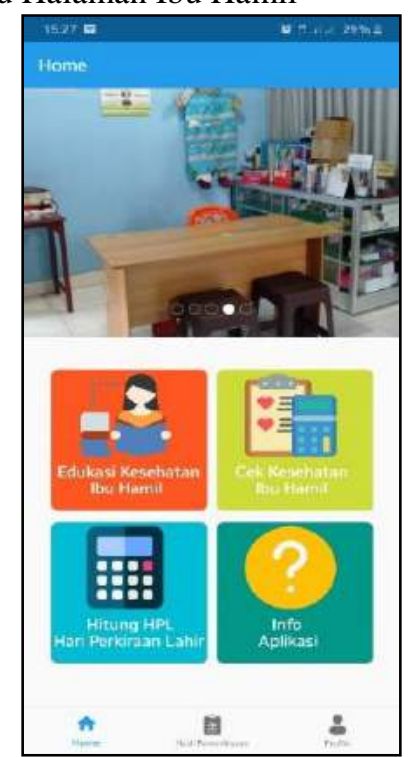

Gambar 16. Menu Halaman Ibu Hamil

Halaman utama ibu hamil terdapat bottom navigation view yang berupa home,hasil pemeriksaan dan profile. Selain itu juga terdapat slide gambar, button edukasi kesehatan ibu hamil, cek kesehatan ibu hamil, hitung Hari Perkiraan Lahir (HPL) dan info aplikasi.

\section{d. Halaman Edukasi Ibu Hamil}

Halaman edukasi ibu hamil dimana terdapat menu keluhan ibu hamil dan perkembangan janin. Menu keluhan ibu hamil digunakan untuk pindah ke halaman edukasi keluhan ibu hamil. Menu perkembangan janin digunakan untuk pindah ke halaman edukasi perkembangan janin. Button back digunakan untuk kembali ke halaman utama.

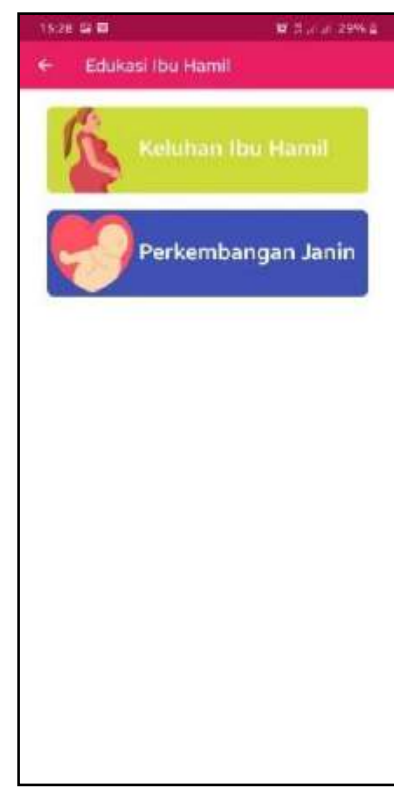

Gambar 17. Halaman Edukasi Ibu Hamil

e. Keluhan Ibu hamil

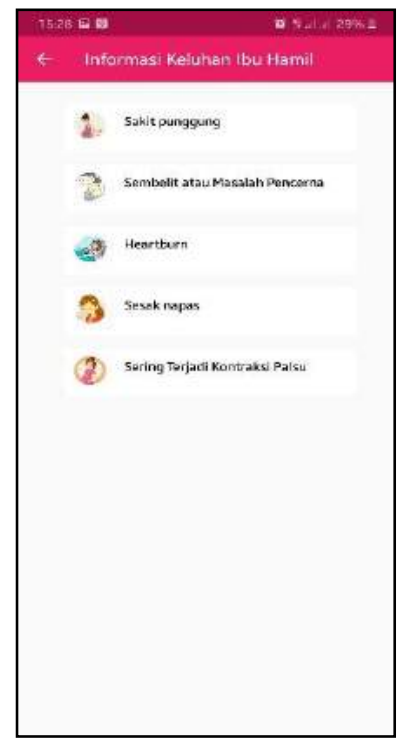

Gambar 18. Keluhan Ibu hamil

Halaman edukasi keluhan ibu hamil dimana terdapat textview yang menampilkan data keluhan. Button back digunakan untuk kembali ke halaman edukasi ibu hamil.

\section{f. Halaman Perkembangan Janin}

Halaman edukasi perkembangan janin dimana terdapat textview yang menampilkan data perkembangan janin. Button back digunakan untuk kembali ke halaman edukasi ibu hamil. 


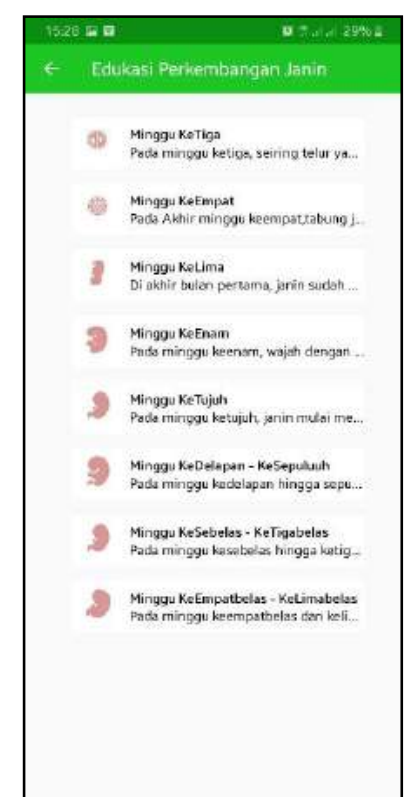

Gambar 19. Halaman Perkembangan Janin

g. Hitung HPL

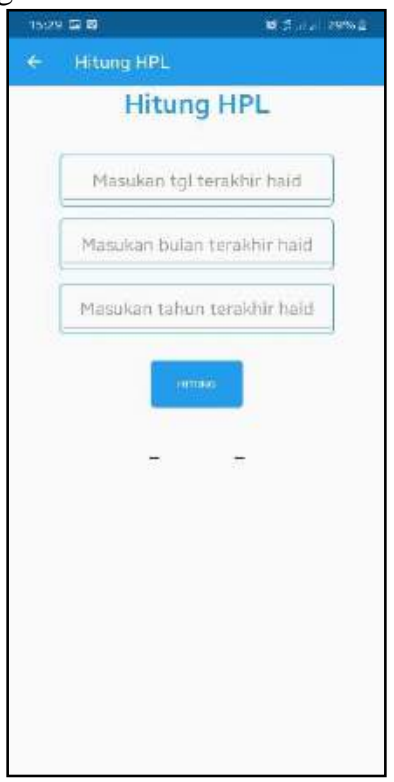

Gambar 20. Hitung HPL

Halaman hari perkiraan lahir ( HPL) terdapat button hitung serta edit text hari, bulan, tahun. Button hitung digunakan untuk menghitung hari perkiraan lahir bayi.

h. Halaman Cek Kesehatan

Halaman cek kesehatan terdapat dua button yaitu cek dan hitung. Selain itu juga terdapat edit text berat badan, tinggi badan, IMT (Indeks Massa Tubuh), tekanan darah, tinggi fundus uteri, denyut jantung janin, lingkar lengan atas. Button cek digunakan untuk mengecek data yang telah di input masing-masing edit text. Sedangkan button hitung digunakan untuk menghitung IMT.

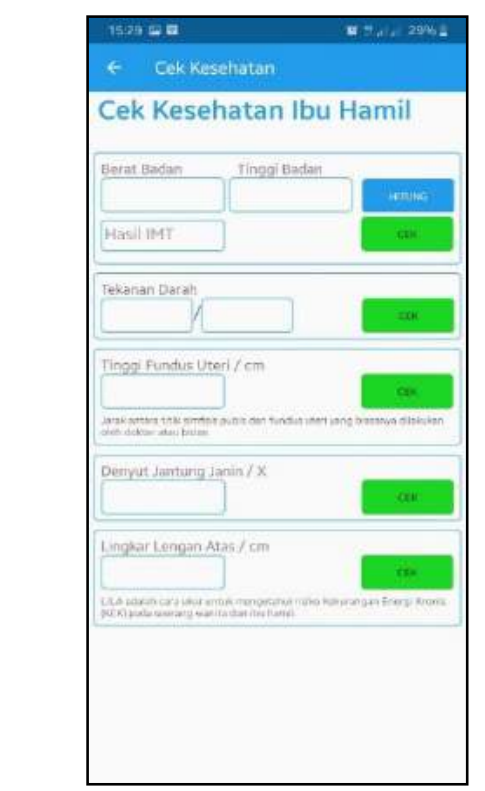

Gambar 21. Halaman Cek Kesehatan

\section{KESIMPULAN}

Aplikasi Kesehatan ibu hamil yang telah dibuat dalam bentuk prototipe yang dapat dijalankan pada sistem operasi android smartphones. Penggunaan aplikasi terbagi menjadi dua users antara lain bidan dan ibu hamil. Fitur unggulan dari aplikasi ini, bahwa ibu hamil dapat berkomunikasi dengan bidan menyampaikan keluhan, hasil pemeriksaan dan informasi seputar kehamilan. Semua data tersebut dilengkapi dengan informasi tanggal, sehingga dapat digunakan sebagai proses monitoring kehamilan. Selain itu, terdapat menu perhitungan Hari Perkiraan Lahir (HPL) yang dapat digunakan untuk memprediksi tanggal kelahiran bayi.

\section{DAFTAR PUSTAKA}

Agustha, K. V., \& Fachrizal, M. R. (2017). Perancangan Sistem Informasi Geografis Fasilitas Pelayanan Kesehatan di Kota Bandung Berbasis Android. Jurnal Teknologi Dan Informasi, 7(1), 67-77.

Aji, A. H., Furqon, M. T., \& Widodo, A. W. (2018). Sistem Pakar Diagnosa Penyakit Ibu Hamil Menggunakan Metode Certainty Factor ( CF ). Jurnal Pengembangan Teknologi Informasi Dan Ilmu Komputer, 3(5), 2127-2134. http://jptiik.ub.ac.id/index.php/jptiik/article/view/1556

Alfarisi, S. (2019). Aplikasi Media Pengenalan Jenis Kamera dan Lensa Berbasis Android. Jurnal Sisfotek Global, 9(1), 124-130. 
Baroroh, I., Jannah, M., \& Meikawati, P. R. (2017). Hubungan Pengetahuan Ibu Hamil Dengan Keikutsertaan Kelas Ibu Hamil Di Wilayah Kerja Puskesmas Jenggot Kota Pekalongan. Siklus: Journal Research Midwifery Politeknik Tegal, 6(2), 212217. https://doi.org/10.30591/siklus.v6i2.579

Dewi, R. G. A. I. (2017). Pengaruh Kemampuan Ibu Hamil dalam Melakukan Deteksi Dini Resiko Preeklamsia Terhadap Paritas, Pengetahuan dan Keterpaparan Informasi. Medical Technology and Public Health Journal, 1(1), 27-34.

Dharmayanti, I., Azhar, K., Hapsari, D., \& H, P. S. (2019). Pelayanan Pemeriksaan Kehamilan Berkualitas yang Dimanfaatkan Ibu Hamil untuk Persiapan Persalinan di Indonesia. Jurnal Ekologi Kesehatan, 18(1), 60-69.

Hikmatulloh, H., Rahmawati, A., Wintana, D., \& Ambarsari, D. A. (2019). Penerapan Algoritma Iterative Dichotomiser Three (ID3) Dalam Mendiagnosa Kesehatan Kehamilan. Klik - Kumpulan Jurnal Ilmu Komputer, $\quad 6(2), \quad 116$. https://doi.org/10.20527/klik.v6i2.189

Indriyanti, E. R., \& Wibowo, S. (2020). Bisnis Kesehatan Berbasis Digital: Intensi Penggunaan Aplikasi digital halodoc. Jurnal Pengabdian Dan Kewirausahaan.

Nur, M. S. K., Khoiriyah, H. I., \& Kurniawan, D. (2018). Pengembangan Model Pendidikan Kesehatan Pada Ibu Hamil Untuk Menurunkan Angka Kematian Ibu Di Kabupaten Bogor. Jurnal Program Kreatifitas Mahasiswa, 2(1), 23-30. https://doi.org/10.32832/pkm-p.v2i1.198

Prasanti, D., \& Fuady, I. (2017). Hambatan Bidan Kepada Ibu Hamil Dalam Upaya Penurunan Angka Kematian Ibu (AKI) di Serang. Jurnal Nomosleca, 2(2). http://jurnal.unmer.ac.id/index.php/n/articl e/view/606

Putri, Mutiara, I., \& Ismiyatun, N. (2020). Deteksi Dini Kehamilan Beresiko. Jurnal Kesehatan Masyarakat, 40-51.

Respati, S. H., Sulistyowati, S., \& Nababan, R. (2019). Analisis Faktor Determinan Kematian Ibu di Kabupaten Sukoharjo Jawa Tengah Indonesia. Jurnal Kesehatan Reproduksi, 6(2), 52. https://doi.org/10.22146/jkr.43463

Sarumaha, V. D., Agustin, F., Tanjung, D. Y. H., Tanjung, H., Teknik, J., Universitas, I., Utama, P., Jurusan, D., Informasi, S., Potensi, U., \& Utama, U. P. (2020). Rancang Bangun Aplikasi Client - Server Control Slide Presentation Berbasis Desktop Dan Android. Jurnal Mahasiswa Fakultas Teknik Dan Ilmu Komputer, 1(1),
781-792.

Selvia, A., \& Ernawati, D. (2019). Manfaat dan Kegunaan Aplikasi Berbasis Seluler sebagai Media Informasi dalam Kehamilan : Review Artikel. Jurnal Bidan Komunitas, $2(2), \quad 76$. https://doi.org/10.33085/jbk.v2i2.4327

Sunjaya, A. P. (2019). Potensi, Aplikasi dan Perkembangan Digital Health di Indonesia. Journal of Indonesian Medical Association, 69(April), 167-169.

Tamrin, T., \& Ma'arif, S. (2020). Android Base Rapid Application Development for Learning Yanbu, a. Journal of Applied Intelligent System, 5(2), 91-97. 